\section{THE ENGLISH ARCTIC EXPEDITION}

$T H E$ edge has been to some extent taken off the public appetite for a narrative of our last great Arctic expedition. The two ships had barely touched the Irish shores ere the papers of the day were teeming with details of the adventures and results of the expedition that had left England scarcely eighteen months before amid the enthusiasm of the nation, and with the strongest expectations of eclipsing all previous expeditions, and returning with the long-sought-for secret of the pole. These newspaper narratives were shortly followed by Capt. Nares's report (which we gave in full with a map in NATURE, vol. xv. p. 24), followed some months after by a thick Arctic blue-book, which those who have seen it may prefer, with its wealth of maps and illustrations, even to the two handsome volumes before us. (See NATURE, vol. xv. p. 505.) Under these circumstances it will not be necessary for us to repeat the story of the Alert and Discovery. We shall endeavour briefly to sum up the main results obtained by the well equipped and much instructed expedition.

Many a wonderful story lies buried in a blue-book; comparatively few, we believe, have seen the official narratives to which we refer above. The great majority of those, both at home and abroad, who are interested in the expedition commanded by Sir George Nares, have no doubt been waiting for the publication of these volumes, to learn all the details of the story of the hardships endured by our ever-brave sailors "far from all men's knowing," in the most inhospitable region under the heavens. The red-tapeism and stupid conservatism of our government are in nothing more forcibly exhibited than in their obstinate adherence to the unattractive "bluebook" for publications of all kinds that may be considered in any way official. In this respect they present a marked contrast to the United States Government, the story of whose Polaris expedition was issued not long ago in a magnificently got-up volume that would do credit even to Messrs. Sampson Low and Co. ; and many of our readers must be familiar with the splendid library, issued at the expense of the Austrian Government, on the productive Novara expedition.

We are sure Sir George Nares does not expect to be complimented on his skill as a raconteur; he has wisely not attempted to do more than give a plain statement of the proceedings of the expedition day by day from the time it left England till its return. Those of our readers who have read the eloquent and methodical narrative of the Payer-Weyprecht expedition, when they look into the one before us, will not fail to be struck with the contrast in this respect. Still, we believe, by many, Sir George Nares's "plain, unvarnished tale" will be preferred to a carefully redacted and condensed narrative; and we are sure that in his pages the simply told successes and failures of the English Arctic Expedition of 1875-76 will fascinate many a reader : it is almost impossible to make the story of an Arctic Expedition uninteresting.

"The scope and primary object" of the expedition was, as contained in the "Sailing Orders," "to attain the highest northern latitude, and, if possible, to reach the North Pole, and from winter quarters to explore the adjaccnt coasts within the reach of travelling parties." Notwithstanding the ambiguous wording of these ordersno doubi "the highest northern latitude possible" was meant-it is a great mistake to imagine, as many did on the return of the expedition, that it was a failure because it did not reach the pole. No doubt it was a primary part of the programme to make the most determined attempt to reach $90^{\circ} \mathrm{N}$. lat., and had "the People" not

I "Narrative of a Voyage to the Polar Sea during $1875-76$, in H.M. ships Alert and Discovery." By Capt. Sir G. S. Nares, R.N., K.C.B., F.R.S., Commander of the Expedition. With Notes on the Natural History, edited by H. W. Fellden, .Gs., C.M.Z.S, Natiralist been allowed to believe that this was the main object of the expedition, probably their enthusiasm at its departure would have been no greater than when the Challenger left our shores; but, without doubt, the essential point in this matter was to get as far north as possible. No one who reads Sir George Nares's interesting but often sad pages will hesitate to conclude that if a higher latitude than that attained by the forlorn hope, led by Commander Markham, was not reached, neither officers nor men were to blame. Under hardships that could only be paralleled by those which led to the unknown deaths of the members of the Franklin expedition, was the attempt made to carry out the popular part of the programmehardships, however, which did not surpass those endured by the sledging parties west and east under Aldrich and Beaumont. This is not the place to enter upon the question of the outbreak of scurvy, to which we have, indeed, referred in a former volume (xv. p. 505). After the searching inquiry of the Scurvy Commission; after all that has been written on the subject in the public and medical journals; and after a careful perusal of these pages, we are not inclined greatly to blame either Captain Nares or his officers for their neglect of lime-juice. Evidently we have yet much to learn about the causes and means of prevention of scurvy. All we have to do with here is the fact that under the most adverse conditions imaginable officers and men did more than could reasonably have been demanded of them-though not expected of English sailors-to carry out the purely geographical part of their orders. Markham and his men really reached the highest latitude possible under the circumstances, $83^{\circ} 20^{\prime} 26^{\prime \prime}$ N., the highest latitude reached by any expedition. "C'est magnifique, mais ce n'est pas la guerre." It was heroic, but it is not what we want.

The other part of the geographical section of the programme was carried out with equal faithfulness by the sledge parties under Lieuts. AIdrich and Beaumont, and, in the case of the latter, under even greater hardships and with greater fatality than in the case of the northern party. Lieut. Aldrich succeeded in adding to our maps a stretch of 220 miles of coast along what may be regarded as the northern boundary of America, while Lieut. Beaumont considerably extended our knowledge of the north coast of Greenland, and has given us reason to believe that it is bordered by islands. Many rectifications were made, moreover, of the geography of the coasts and islands in Kennedy and Robeson channels, and a considerably fuller and more accurate idea of the nature of the coast regions both on the east and west sides of these channels. The fact is that, geographically, there appears to be little to discover in the region around the Alert's winter quarters, and what is really worth knowing in this direction could only be brought to light by an expedition colonised there for some years; Capt. Howgate's proposed experiment will therefore be anxiously watehed. Though it was often difficult to tell where the sea-ice ended and the land began, enough was observed both by Aldrich and Beaumont to indicate that these northern shores are mostly rocky, rising rapidly into hills and mountains, and often, especially on the Greenland side, steep and imposing, and deeply cut into by fiords. Markham saw no sign of land as far beyond his farthest north point as he could see, and seems inclined to believe that if there is land it must be a great way off.

Even had the men maintained their health and strength, it is doubtful if any of the sledging parties would have been able to do much more than they did, unless, indeed, they had been able to stay another winter, and make their furthest points bases for farther operations. The great hindrance to progress was the character of the ice which the sledge-parties had to traverse. The nature of this characteristic feature of these regions, the "palæocrystic ice," as it has peen named, is already 
well known to our readers, and some further idea of it may be obtained from the specimen shown in our illustration (Fig. I). Things were bad enough for the shore-parties, but, to judge from the description, it would be as easy to go from the Crystal to the Alexandra Palace over the tops of the houses dragging a heavily-laden sledge after you, as to accomplish what Markham and his party did. The valuable result of this expedition is an extension of our knowledge of the nature and formation of the ice which covers these polar regions. That the inconceivably rugged and hilly nature of the ice is partly due to the movement of the pack, and the consequent piling of floe on floe at all sorts of angles, there can be no doubt; but the observations of Dr. Moss (see our Royal Society Report this week) and Lieut. Parr seem to show that the immense thickness of the floes, exceeding eighty feet sometimes, is not due cntirely to the piling of floe on floe. Rather it would seem that the same causes are in operation here as in the Alpine glaciers, and that on a thick substratum of sea-ice, snow-fall after snow-fall has been accumulating season after season,- for how long the daring geologist alone can hazard a guess-becoming gradually condensed into ice by pressure. What may be the limit of this process we have no data on which to build conclusions. "The Névé-like stratification, the embedded atmospheric dust, and the chemical characters of our polar floes, indicate, in my (Dr. Moss's) opinion, that they are the accumulated snow-fall of ages, rendered brackish by infiltration and efflorescence." The great "domed" floes, he thinks, tell of gradual decay, "because, wherever we got a section of them, the horizontal strata were cut by the outline of the domes, and the ice of the top of the dome was invariably salt. Occasionally deposits of atmospheric dust were to be met with throughout the stratified ice."

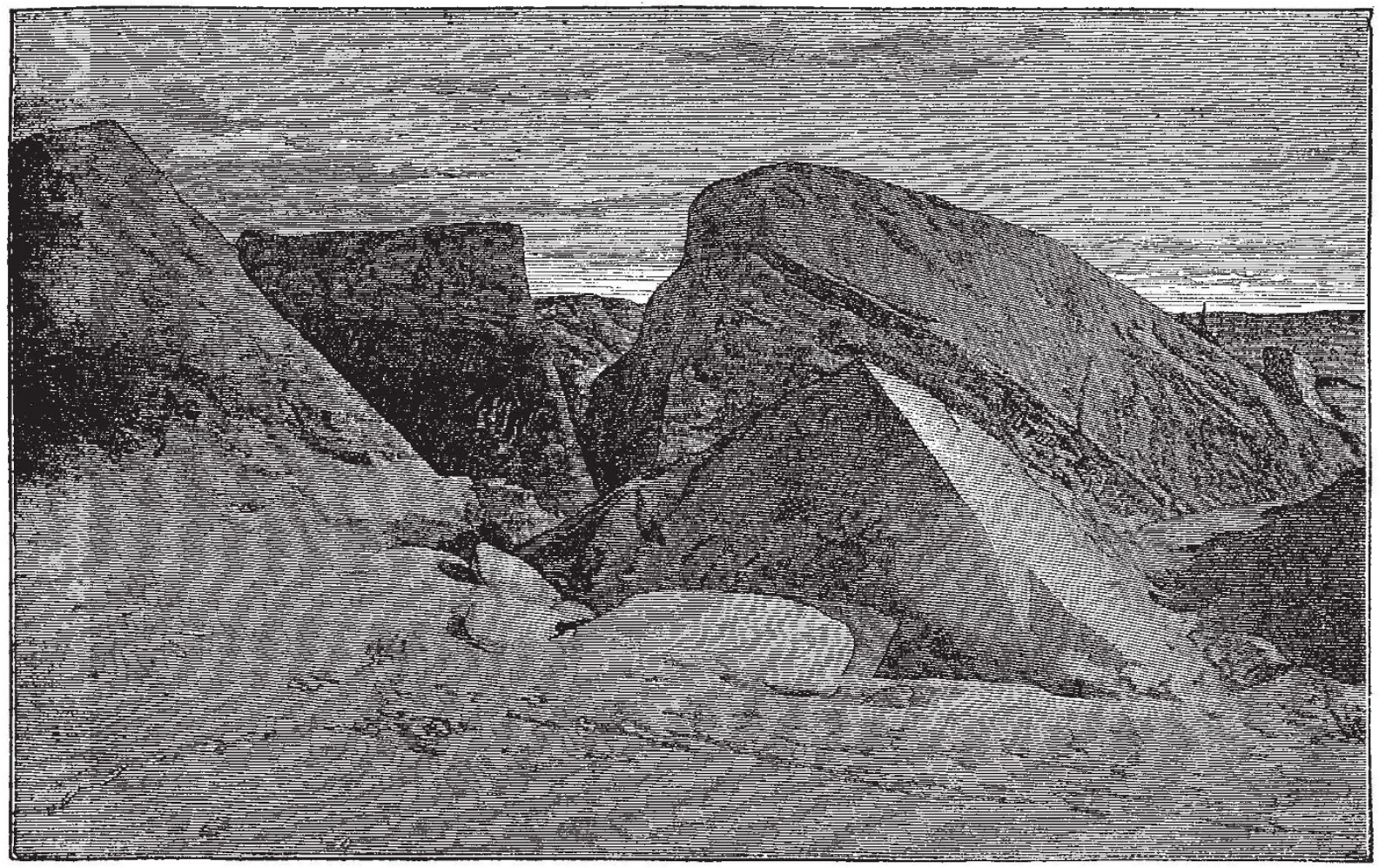

Fig. x.-Newly-formed Flce-bergs.

As to the movements of the ice in the Polar Occan, the expedition was unable to make any observations of consequence, though it has made some contributions to a knowledge of those of the ice in the channels through which the ships passed. The general conclusion scems to be that beyond the Alcrt's winter quarters, though there may be occasional open spaces, or polynias, the ice never breaks up sufficiently to enable a ship to pass further northwards, notwithstanding the observations made by the Polaris expedition. But this question of the movements of the polar ice is just one of those that can only be satisfactorily settled by a long series of observations, such as those that could be made from the ring of stations proposed to be established by Lieut. Weyprecht.

The tidal observations made, especially on board the Discovery, were of great value, in the opinion of Dr. Haughton, who gives an abstract of the results in the Appendix, and seem to confirm the observations made in the Polars expedition:- "The expedition, proceeding up Smith Sound, met the tide coming from the north, at or near Cape Frazer, lat. $79^{\circ} 40^{\prime}$, and left behind the tides of Baffin's Bay. The new tidal wave, observed on board both ships, is specifically distinct from the Baffin's Bay tide, and from the tide that enters the Arctic Ocean through Behring's Straits ; and it is, without question, a ticle that has passed from the Atlantic Ocean, round Greenland, northwards, and then westwards."

As might be expected in these high northern regions, there were few auroral displays, and though one, at least, was remarkable, none were brilliant, and all comparatively colourless. We do not read, however, that any attempt was made to study this or any other light phenomenon by means of the spectroscope, though, we believe, several of the officers were specially instructed in the use of the instrument before the expedition set out. In this connection we may notice a most interesting solar phenomenon 
exhibited on p. 300 of vol. i. (see Fig. 2), which will give the reader some idea as to how snow-blindness may be produced, and which might have reminded Capt. Nares that the expedition was provided with the instrument we speak of. When the sun reaches a certain height, above $14^{\circ}$, during clear weather, "the most brilliant prismatic colours are displayed by each minute snow-prism, and in combination form a sparkling arc on the snow-covered ground, the bright light from which is too powerful for the unprotected eye. The 'diamond-dust,' as we term it, becomes more open as the length of the radius is increased. Consequently, when the sun is between fourteen and twenty-three degrees in altitude, the refraction of its rays is set forth with the greatest effect, and snow-blindness has to be guarded against. In the bright arc, while each tiny prism displays its complete set of colours, the red tint is the most prominent nearest the sun, the purple lying on the outside indistinctly defined.' We regret that such observations were so rare, and that so little use was made by the expedition under Capt. Nares of the fine set of apparatus for physical observations with which it was provided. This is the weak point of the expedition, and, so far as physical science is concerned, the "Arctic Manual" need hardly have been written. The 26 th paragraph of the sailing orders runs :

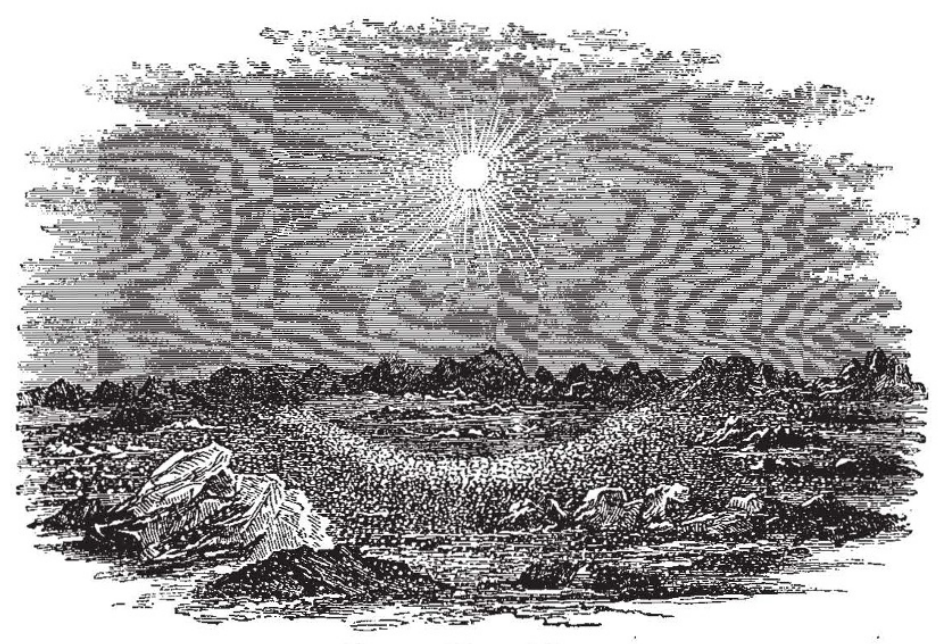

Fig. 2.-Diamond Dust.

"The most approved instruments have been furnished to you for the purpose of pursuing research in the several branches of physical science, and as certain of your officers have been specially instructed in the modes of observing, you will take care to give them every fair opportunity of adding their contributions thereto." Very few "fair opportunities" seem to have occurred to the expedition.

But after all it is doubtful if the commander of the expedition is so much to blame. The truth is that the instructions to the expedition said more than should have been said about trying to reach the pole. What we wanted and what we still want are steady continued observations of meteorological and other phenomena in the polar area. The Royal Society might have saved itself all trouble if the instructions had been published beforehand. The comparative meagreness of the scientific results is, we believe, due more to the tone of the instructions than to Sir George Nares.

Thanks mainly to Capt. Feilden, however, the expedition has not been altogether barren in scientific results, as the Appendix filling half the second volume will testify. With the exception of the short paper on the tides by Dr. Haughton, this appendix deals with the natural history and geology of the region visited. Each of the departments of natural history, from the mammalia downwards, has been worked out by a specialist, and the results, though seldom novel, are all highly interesting. Life was found in the sea at the highest point reached, and not far from the same point the tracks of a hare were seen. Dr. Hooker has some important observations to make in connection with the flora brought home, which confirms his previous conclusions as to the essentially Greenlandish nature of the Greenland flora. $\mathrm{He}$ is inclined to think that regetation may be more abundant in the interior of Greenland than is supposed, and that the glacier-bound coast-ranges of that country may protect a comparatively fertile interior. We are almost driven to conclude, he thinks, that Grinnell Land, as well as Greenland, are, instead of ice-capped, merely ice-girt lands. The geological results are fully and ably discussed by Mr. De Rance and Capt. Feilden, who indeed traverse summarily the whole ground of Arctic geology, to which their paper is a valuable contribution. Their conclusions are essentially the same as those already formed as to the very different climate that must have at one time prevailed in these regions. Dr. Coppinger's report on the great glacier that discharges into the Petermann Fjord is interesting, though his observations do not seem to agree entirely with Dr. Hooker's conclusions.

On the whole Sir George Nares's two volumes confirm the opinions we have already published with regard to this expedition: One and all exerted themselves nobly and bravely to carry out the main object of the expedition; the results, geographical and scientific, brought home are of great value, and repay to a considerable extent the outlay and the hardships endured; at the same time, now that the full narrative has been published, we must express regret that the scientific results are not more abundant than they are, and that they contrast so markedly with those of previous English expeditions, and with the expeditions of Germany and Austria, where, however, the officers are all trained men of science. Notwithstanding the results we cannot regret that the expedition was sent out; it has solved the question of Arctic exploration so far that it is clear the Pole is not to be reached by the Smith Sound route -if at all, indeed by any means hitherto tried -unless some line of land be met with that will enable the sledge to be utilised. Meantime this narrative of the last great English Expedition will prove attractive and instructive to many readers. We cannot conclude without saying a word in praise of the many fine illustrations of Arctic scenery, a number of the finest being permanent Woodburytypes. There is also a large map showing the new discoreries, and a special one of Markham's journeys.

\section{TRANSPLANTATION OF SHELLS}

$\mathrm{T}^{\mathrm{T}}$ is well known that animals and plants inhabiting freshwater have, as a general rule, a very wide distribution; yet each river system, with all the pools and lakes in connection with it, seems completely cut off from every other system of the same country. Still more complete is the separation between the freshwaters of distinct continents or of islands; nevertheless they often possess freshwater species in common. In my "Origin of Species" I have suggested various means of transportal; but as few facts on this head are positively known, the case given in the adjoined letter of a living Unio, which had caught one of the toes of a duck's foot 